\title{
EVALUACIJA FAKTORA ZNAČAJNIH ZA NIVO UČEŠĆA NA TRŽIŠTU ORGANIZACIJA KOJE POSLUJU U REPUBLICI SRBIJI*
}

\author{
Nikola Ćurčić \\ Institut za ekonomiku poljoprivrede, Beograd \\ Slavomir Miletić \\ Univerzitet u Prištini, Ekonomski fakultet u Kosovskoj Mitrovici \\ Aleksandar Grubor \\ Univerzitet u Novom Sadu, Ekonomski fakultet u Subotici \\ Zoran Simonović \\ Institut za ekonomiku poljoprivrede, Beograd
}

\begin{abstract}
ovom radu predmet istraživanja je poslovni uspeh organizacije koji se odnosi na ocenu faktora značajnih za ostvarenje željenog tržišnog učešća, pri čemu se uvažava činjenica da se njegova veličina učešća ne može jednom zauvek definisati. Cilj istraživanja je da se evaluiraju faktori bitni za povećanje nivoa tržišnog učešća organizacija koje posluju u Srbiji, kao posebno odabranog cilja i identifikuje njihova važnost za uspešnost poslovanja kako u nacionalnim okvirima, tako i van nacionalnih granica. Istraživanje je sprovedeno na bazi posebno osmišljenog upitnika na uzorku od 100 organizacija koje posluju na teritoriji Srbije. Bilo je 96 vraćenih i valjano popunjenih upitnika koji su uzeti u obzir prilikom obrade podataka. Korišćene metode u ovom istraživanju su hipotetsko-deduktivne, analitičko-deduktivne i komparativne metode, istorijske i statističko - deskriptivne metode i metode komparativne statistike. Ključni rezultati istraživanja potvrdili su da se tržišno učešće pokazalo kao bitno za uspešnost poslovanja organizacija odabranih u uzorku. Najvažniji faktor od značaja za nivo tržišnog učešća je dosadašnja reputacija, slede karakteristike tržišta, veličina tržišta, dužina nastupa na tržištu i prisustvo druge organizacije (konkurencije) na tržištu. Rezultati istraživanja ukazuju i na razlike u ocenama značaja tržišnog učešća za poslovni uspeh u organizacijama različite veličine i različitog nivoa poslovanja.
\end{abstract}

Ključne reči: poslovni uspeh, organizacija, faktori tržišnog učešća

Uvod

7 načaj i uticaj tržišnog učešća na poslovni uspeh organizacije predmet je kontinuirane debate i istraživanja. Za većinu organizacija je od posebnog značaja rast tržišnog učešća, s obzirom da je opadanje udela na tržištu siguran znak da je proizvod po-

\footnotetext{
* Rad je deo istraživanja na projektu III 46006 „Održiva poljoprivreda i ruralni razvoj u funkciji ostvarivanja strateških ciljeva Republike Srbije u okviru dunavskog regiona“ finansiranog od strane Ministarstva prosvete, nauke i tehnološkog razvoja Republike Srbije u periodu 2011-2019.
} 
stao nekonkurentan na datom tržištu. Adekvatna ocena nivoa učešća organizacije na tržištu je važan input koji može da koristi za donošenje odluka iz domena povećanja uspešnosti njene poslovne politike. Međutim, vrlo malo istraživanja je uključilo koncept izučavanja ponašanja organizacija pri generisanju tržišnog udela. Kolokvijalno, povećanje tržišnog učešća organizacijama znači i povećanje njihove profitabilnosti i rast ukupnih performansi. Ranije objavljene studije koje su se bavile istraživanjem tržišnog učešća, pokazivale su da većina organizacija sa velikim tržišnim učešćem uživa vanprosečne profitne margine (Schoeffler, Buzzell, 1974), iako su neke studije pokazale da i organizacije sa niskim tržišnim učešćem mogu biti uspešne i konkurentne u određenim okruženjima (Hamermesh, Anderson, Jr., 1978).

Ukupni rezultati istraživanja sprovedenih krajem prošlog veka, ukazali su na određene limite u smislu da ne mogu poslužiti kao recept za povećanje tržišnog učešća organizacija u različitim industrijama. Spoznaja je da je većina studija rasta tržišnog učešća primenjiva samo kod organizacija u zrelim industrijama (Buzzell, Wiersema, 1981), s tim da se vrlo malo studija bavilo strategijama kao faktorom povećanja tržišnog učešća u različitim konkurentnim okruženjima.

Postoje uspešne strategije povećanja tržišnog učešća, ali većina njih tiču se samo marketinga. Jasno je da je visoko tržišno učešće povezano sa visokim kvalitetom proizvoda (Hellofs, Jacobson, 1999), visokim marketinškim troškovima i uvođenjem novog proizvoda na tržište (Porter, 1980). Adekvatne strategije organizacija, svakako, imaju značajan uticaj na povećanje tržišnog udela i njenu uspešnost. Zbog toga je neophodno da se kontinuirano preispitaju faktori uspešnosti, kako bi se učešće na tržištu održavalo i/ili povećavalo. Organizacije koje funkcionišu u istim ili sličnim okruženjima mogu se nadmetati koristeći različite kompetitivne metode (Namiki, 2011, str. 50-52) zahvaljujući nesličnim strateškim orijentacijama njihovog menadžmenta i drugih internih karakterističnih sposobnosti. Upečatljivo je da organizacije sa mogućnošću inovacije i to ne samo proizvoda, generalno imaju bolje performanse i veće tržišno učešće od drugih. Zato se menadžeri inovativnih organizacija fokusiraju na jednu od strategija rasta tržišnog učešća - targetiranje potrošača (Namiki, 2011) koji stalno menjaju svoje potrebe ili brzog odgovora njihovim servisnim zahtevima.

U poslovnoj praksi privrednih subjekata izdvajaju se različiti faktori koji značajno utiču na nivo tržišnog učešća, a time i na ukupni poslovni uspeh organizacija. Kako bi se efikasno upravljalo tržišnim učešćem neophodno je da organizacije u Srbiji identifikuju i ocene ključne faktore od značaja za nivo njihovog udela na tržištu i preciziraju granice svog tržišta. Ovi faktori, pre svih reputacija organizacije, karakteristike i veličina tržišta (Stojanović, 2005 , str. 34), značaj prisustva drugih organizacija (konkurencije) na tržištu i, dužina nastupa organizacija na tržištu su predmet empirijskog istraživanja i analize u ovom radu u smislu utvrđivanja apsolutne i srednje vrednosti njihovih ocena značajnih za nivo udela na tržištu i važnost svakog pojedinačnog faktora za poslovni uspeh konkretne organizacije.

Istovremeno, primenom ANOVA testa izvedene su razlike u ocenama značaja tržišnog učešća organizacija različite veličine i različitog nivoa poslovanja za poslovni uspeh organizacije u nacionalnim okvirima i van nacionalnih granica. Takođe, predstavljena je korelacija faktora od značaja za nivo tržišnog učešća i postojanje razlika u ocenama uticaja menadžmenta u funkciji povećanja tržišnog učešća u organizacijama različite veličine i različitog nivoa poslovanja. 
Vojnoekonomski pregled

Učešće na tržištu (Ćurčić, 2017, str. 37) kao i drugi ključni faktori uspeha organizacije imaju neograničen potencijal upotrebe, ali kao i većina drugih alata, oni su efektivni onoliko koliko je efektivna njihova primena. Spoznaja potrebe za upravljanje tržišnim učešćem kao pretpostavke poslovnog uspeha (Tadić, Boljević, 2015) svake organizacije postaje sve značajnije pitanje, upravo usled rapidnih i stalnih promena tehnologije, dinamike i globalizacije poslovanja i internacionalizacije tržišta.

\section{Teorijski okvir istraživanja}

U svakoj organizaciji najčešće merilo njenog poslovnog uspeha uz profitabilnost, rast i satisfakciju potrošača je tržišno učešće (Perren, 2000). Ono predstavlja procentualni udeo (Carlton, Perflof, 2005) u ukupnoj prodaji jednog proizvoda koji otpada na jednu organizaciju. Obično se identifikuje kao odnos plasmana proizvoda konkretne organizacije prema prodaji grane - posmatrane delatnosti (Aaker, et. al. 2008, str. 682). U funkciji praćenja poslovnog uspeha organizacije, može se kvantifikovati na različite načine:

- naturalno,

- vrednosno ili

- njihovom kombinacijom.

Ukoliko se tržišno učešće izražava u jedinicama proizvoda, tada su promene tržišnog učešća rezultat promena u obimima prodaje konkurencije, a ako se izražava vrednosno onda njegova promena odražava promene i obima i cene. Na brojnim tržištima, jedinica tržišnog učešća vredi desetine miliona dolara (Kotler, 2000). No, bez obzira na modalitet izražavanja tržišnog učešća neophodno je precizno definisati proizvod/ uslugu, tržište i vreme na koje se tržišno učešće odnosi. Granice tržišta se moraju precizirati - da li je reč o lokalnom, regionalnom, nacionalnom ili međunarodnom tržištu; kao i nivoi u definisanju tržišta - da li se tržišno učešće izražava u odnosu na potencijalno, raspoloživo, kvalifikovano, opsluženo ili osvojeno tržište.

Pojedine organizacije koriste tržišno učešće, ako ne kao bazični, a ono kao jedan od važnijih ciljeva njenog marketing menadžmenta (Ćurčić, 2018, str. 54) što je i razumljivo ako se uzme u obzir da je ponekad lakše ponovo ostvariti veći iznos dobiti nego povratiti izgubljeni deo tržišta. Odgovor na pitanje o optimalnoj veličini tržišnog učešća nije lako dati, zbog toga što se veličina tržišnog učešća ne može jednom zauvek definisati. Smatra se da je ona proporcionalna veličini napora marketing menadžmenta koji pojedine organizacije ulažu za njegovo osvajanje i zadržavanje (Đorđević, 2014, str. 153).

Svaka organizacija koja posluje na tržištu kontinuirano teži da poveća svoje tržišno učešće, s obzirom da postoji pozitivna korelacija između tržišnog učešća i profitabilnosti. Nastojanje da se osigura veće tržišno učešće za posledicu ima veći nivo koncentracije ponude (Amato, Wilder, 2004, 142).

Promena tržišnog učešća tokom vremena je važan pokazatelj dinamike uspešnosti poslovanja (Aaker, i dr. 2008, str. 683). U funkciji ispravnog tumačenja i adekvatnog upravljanja tržišnim učešćem najpre valja utvrditi merilo ili merila tržišnog učešća (Samuelson, Nordhaus, 2001), zatim da se podaci o tržišnom učešću raščlane na različite veličine (proizvode, vrste kupaca, regije) i da se na kraju samo tržišno učešće raščlani na sastavne komponente (penetracija i privrženost kupaca, selektivnost kupaca i cene) što čini osnovu ocene nivoa konkurentnosti organizacije. 
Indikatori tržišnog učešća, apsolutnog i relativnog omogućavaju da se sagleda tržišna pozicija organizacije u odnosu na rivale (Lipezynski, Wilson, 2001). Ukoliko učešće organizacije na tržištu raste, onda ona dobija u odnosu na konkurente, a ako opada, ona gubi u odnosu na konkurente. Ovakvi zaključci analize tržišnog učešća polaze od određenih pretpostavki koje praksa ne potvrđuje baš uvek. U situaciji kada neka nova organizacija uđe u granu to dovodi do smanjenja tržišnog učešća svake od organizacija koje su već u grani, što ne znači da neka organizacija lošije obavlja svoje poslovanje od drugih. Uzrok osciliranja tržišnog učešća mogu biti i brojni slučajni razlozi (Kotler, 1989, str. 772). Ponekad je pad tržišnog učešća rezultat smišljene politike da se poboljša profit.

Učešće na tržištu ne koristi se samo u postavljanju cilja i kontroli poslovnog uspeha već i pri predviđanju prodaje. U granama/ grupacijama privrede gde je učešće na tržištu relativno stabilno - postoji neka vrsta podele tržišta od strane organizacija koje sačinjavaju granu, pa organizacije mogu da izračunaju svoje tržišno učešće (Waldman, Jensen, 2001, str. 95). Projektovanje učešća na tržištu je pogodan način predviđanja, samo ako ga je lako izračunati i ako je stabilno. Ako je učešće na tržištu teško izračunati, i ako još fluktuira u vremenu, ne može se koristiti kao metod predviđanja plasmana, jer može da navede na pogrešne zaključke (Milisavljević, 2002, str. 109).

Odabir opcije održavanja i povećavanja tržišnog učešća organizacije u Srbiji zavisi od potencijalnog efekta na dobit i nivoa rizika svake od korišćenih strategija njegovog povećanja, ali i od zainteresovanosti konkurencije za određene segmente.

\section{Metodologija istraživanja}

S pravom istraživanje poslovnog uspeha organizacije, podrazumeva da taj uspeh mora da uključi iznalaženje rešenja za povećanje željenog nivoa tržišnog učešća. Pretpostavka istraživanja je: Održanje stabilnog razvoja i poslovnog uspeha organizacije zavisno je pored ostalih faktora i od nivoa tržišnog učešća kao operativnog uslova.

$U$ istraživačkom uzorku od 96 preduzeća, $42,7 \%$ su mikro organizacije (organizacije koje imaju više od 9 zaposlenih), 25\% su male organizacije (koje imaju između 10 i 49 zaposlenih), 15,6\% su srednje organizacije (sa 50 do 249 zaposlenih), dok je procenat velikih organizacija (sa preko 250 zaposlenih) 16,7\%. Od posmatranih organizacija u uzorku na lokalnom nivou posluje $18,8 \%$ organizacija, na nacionalnom nivou $22,9 \%$, na regionalnom nivou $26 \%$, dok $32,3 \%$ organizacija deluje na međunarodnom nivou. Najveći broj organizacija postoji više od 15 godina $(38,5 \%)$, organizacija koje posluju od 8 do 15 godina je $31,3 \%$, organizacija koje posluju od 4 do 7 godina je 19,8, dok je najmanje organizacije koje deluju do 3 godine (19,4\%). Većina organizacija obavlja aktivnosti zasnovane na uslugama $(61,5 \%)$, slede organizacije koje obavljaju i uslužne i proizvodne aktivnosti $(22,9 \%)$ i najmanje su one sa isključivo proizvodnim aktivnostima (15,6\%).

$U$ radu su korišćene hipotetsko-deduktivne metode, analitičko-deduktivne metode, komparativne metode, istorijske i statističke deskriptivne metode i metode komparativne statistike (ch2 test, ANOVA). Faktore od značaja za postizanje konkurentske pozicije ocenjivali su ispitanici sa ocenama od 1 do 5 , pri čemu su svaki faktor ocenili u odnosu na njihov stupanj značajnosti (1 - najmanje važan među navedenim faktorima, 5 - najvažniji faktor). 


\section{Rezultati istraživanja}

Razmatrajući faktore od značaja za nivo tržišnog učešća organizacija, rezultati istraživanja pokazuju da je najveći procenat organizacija (45,8\%) ocenilo najvišom ocenom 5 da nivo tržišnog učešća zavisi od dosadašnje reputacije, $29,2 \%$ organizacije je značaj dosadašnje reputacije za nivo tržišnog učešća ocenilo ocenom 2 , ocenom 4 je ocenilo $11,5 \%$, najmanju ocenu 1 dalo je 7,3\% organizacija, dok je ocenu 3 dalo $6,3 \%$ organizacija. Apsolutne vrednosti ocene dosadašnje reputacije kao faktora od značaja za nivo tržišnog učešća predstavljene su u Grafikonu 1.

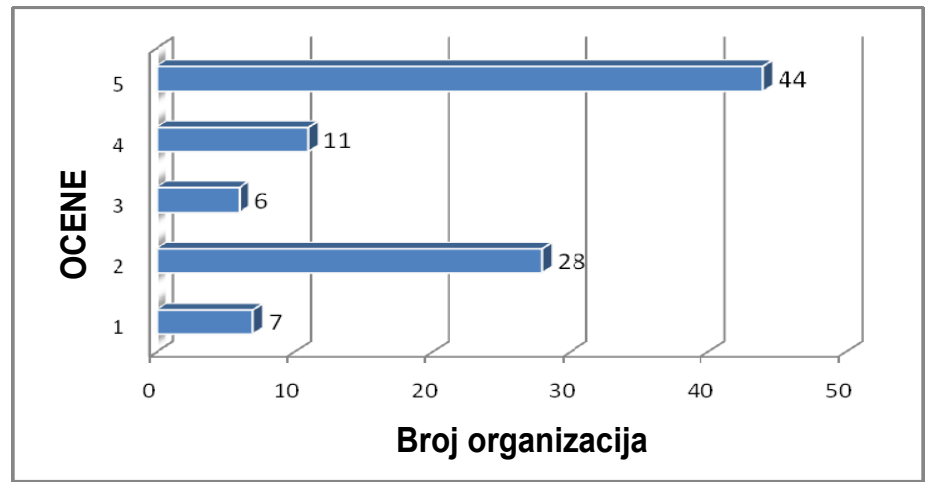

Grafikon 1 - Apsolutne vrednosti ocene dosadašnje reputacije kao faktora od značaja za nivo tržišnog učešća Izvor: Ćurčić, N. (2018). Poslovni uspeh savremene organizacije. IEP, Beograd, str. 153.

Najveći procenat organizacija $(27,1 \%)$ ocenilo je ocenom 3 značaj drugih organizacija na tržištu (konkurenciju) kao faktor od značaja za nivo tržišnog učešća svoje organizacije, isti procenat $(21,9 \%)$ organizacija je ocenilo ocenama 1 i 2 značaj drugih organizacija na tržištu, ocenom 4 ocenilo je 17,1\%, dok je najveću ocenu 5 dalo $11,5 \%$ organizacija. Apsolutne vrednosti ocena drugih organizacija kao faktora od značaja za nivo tržišnog učešća predstavljene su u Grafikonu 2.

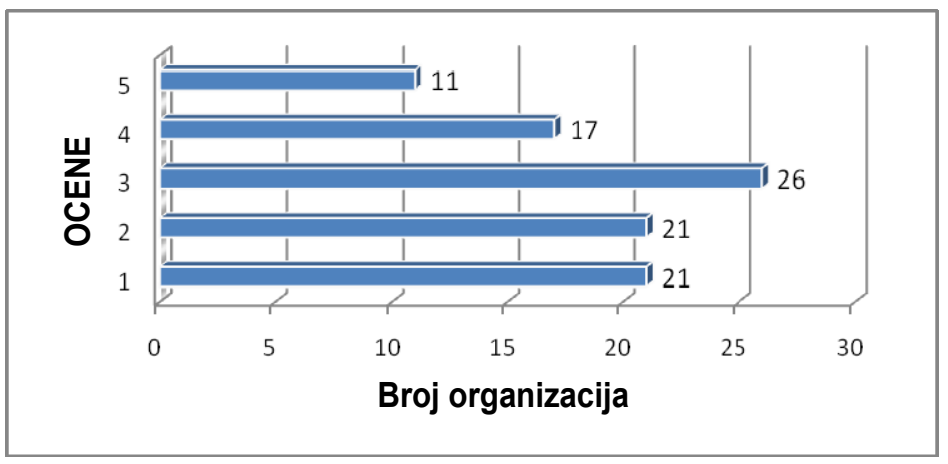

Grafikon 2 - Apsolutne vrednosti ocene drugih organizacija kao faktora od značaja za nivo tržišnog učešća Izvor: Ibidem, str. 154 
Ocene karakteristika tržišta kao faktora od značaja za nivo tržišnog učešća najveći procenat organizacija $(29,2 \%)$ ocenilo je ocenom 3 , ocenu 5 dalo je $20,8 \%$ organizacija, ocenu 2 dalo je 17,8\% organizacija, ocenu 4 dalo je 16,7\% organizacija, dok je najmanju ocenu 1 dalo $15,6 \%$ organizacija. Apsolutne vrednosti ocena karakteristika tržišta kao faktora od značaja za nivo tržišnog učešća predstavljene su u Grafikonu 3.

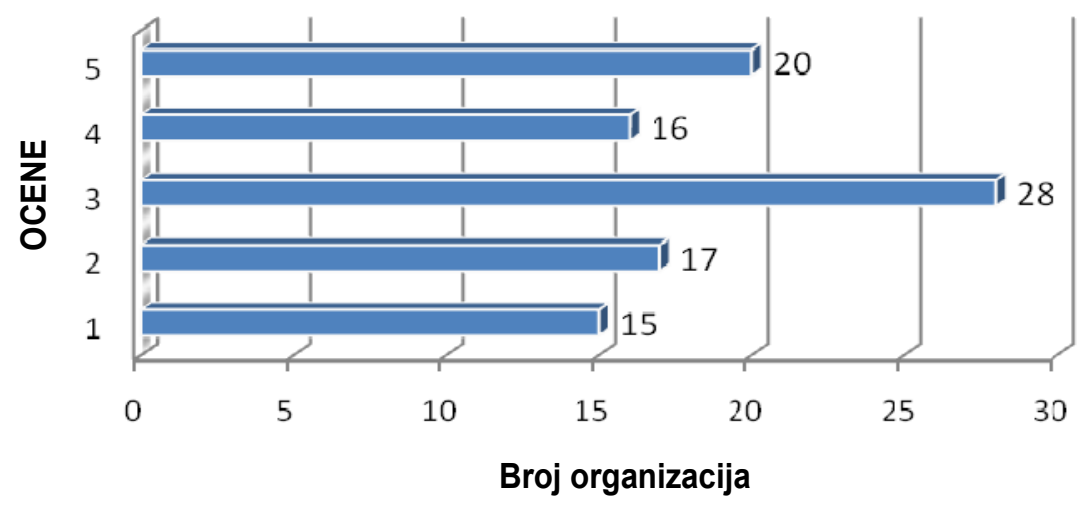

Grafikon 3 - Apsolutne vrednosti ocene karakteristika tržišta kao faktora od značaja za nivo tržišnog učešća Izvor: Ibidem, str. 154.

Najveći procenat organizacija $(27,1 \%)$ ocenilo je veličinu tržišta kao faktor od značaja za nivo tržišnog učešća, najmanjom ocenom $1,25 \%$ organizacija dalo je ocenu 3 , ocenu 4 dalo je 18,8\% organizacija, najvišu ocenu 5 dalo je 15,6\% organizacija, dok je ocenu 2 dalo $13,5 \%$ organizacija. Apsolutne vrednosti ocene karakteristika tržišta kao faktora od značaja za tržišno učešće predstavljene su u Grafikonu 4.

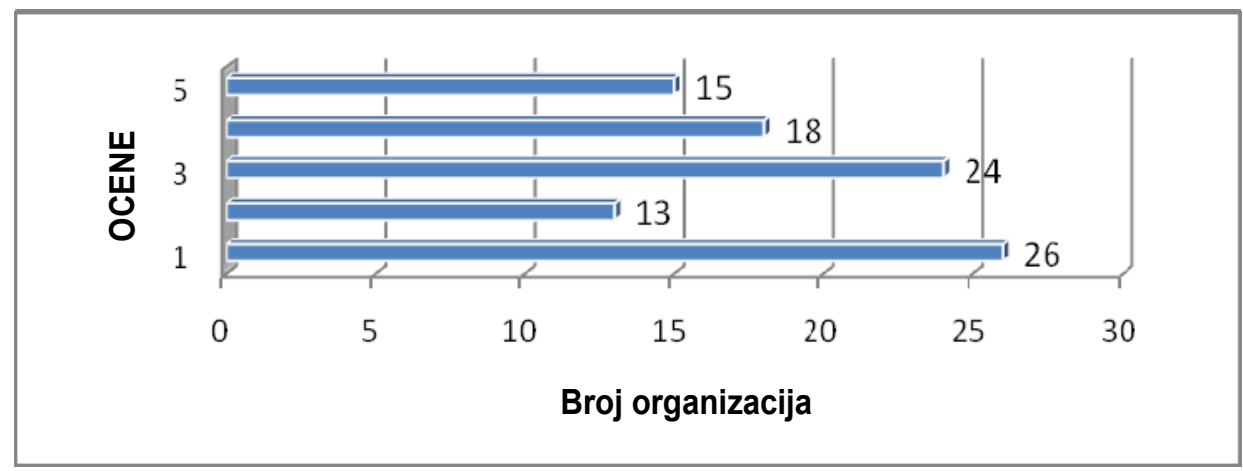

Grafikon 4 - Apsolutne vrednosti ocene veličine tržišta kao faktora od značaja za nivo tržišnog učešća Izvor: Ibidem, str. 155. 
Najveći procenat organizacija $(35,4 \%)$ je dužinu nastupa na tržištu kao faktor od značaja za nivo tržišnog učešća ocenilo ocenom 4, najmanju ocenu 1 dalo je $26 \%$ organizacija, ocenu 2 dalo je 19,8\% organizacija, ocenu 3 dalo je 12,5\% organizacija, dok je najveću ocenu 5 dalo $6,3 \%$ organizacija. Apsolutne vrednosti dužine nastupa na tržištu kao faktor od značaja za nivo tržišnog učešća predstavljene su u Grafikonu 5.

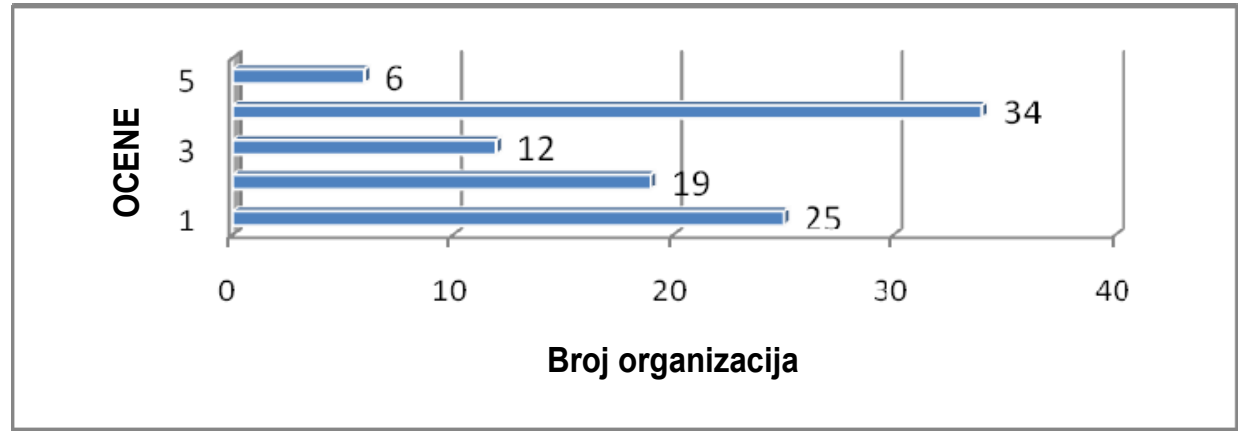

Grafikon 5 - Apsolutne vrednosti ocene dužine nastupa na tržištu kao faktora od značaja za nivo tržišnog učešća

Izvor: Ibidem, str. 155.

U Tabeli 1 predstavljene su srednje vrednosti ocena faktora od značaja za nivo tržišnog učešća. Može se videti da je dosadašnja reputacija ocenjena kao najznačajniji faktor za ostvarivanje tržišnog učešća (srednja vrednost 3,59), slede karakteristike tržišta (srednja vrednost 3,09 ), zatim veličina tržišta, dužina nastupa na tržištu (srednja vrednost 2,76 ) i sa nešto manjom prosečnom ocenom $(2,75)$ druge organizacije na tržištu.

Tabela 1 - Srednje vrednosti ocena faktora od značaja za nivo tržišnog učešća

\begin{tabular}{|l|c|c|c|c|c|}
\cline { 2 - 5 } \multicolumn{1}{c|}{} & $\begin{array}{c}\text { Karakteristike } \\
\text { tržišta }\end{array}$ & $\begin{array}{c}\text { Druge } \\
\text { organizacije } \\
\text { na tržištu }\end{array}$ & $\begin{array}{c}\text { Veličina } \\
\text { tržišta }\end{array}$ & $\begin{array}{c}\text { Dosadašnja } \\
\text { reputacija }\end{array}$ & $\begin{array}{c}\text { Dužina } \\
\text { nastupa } \\
\text { na tržištu }\end{array}$ \\
\hline $\begin{array}{l}\text { Srednje } \\
\text { vrednosti }\end{array}$ & 3.09 & 2.75 & 2.82 & 3.59 & 2.76 \\
\hline
\end{tabular}

Izvor: Ibidem, str 156.

Grafikon 6 pokazuje da je dosadašnja reputacija faktor koji je u najvećem procentu $(45,8 \%)$ ocenjena ocenom 5 , dok je dužina nastupa na tržištu ocenjena ocenom $4 \mathrm{u}$ $35,4 \%$ organizacija. 


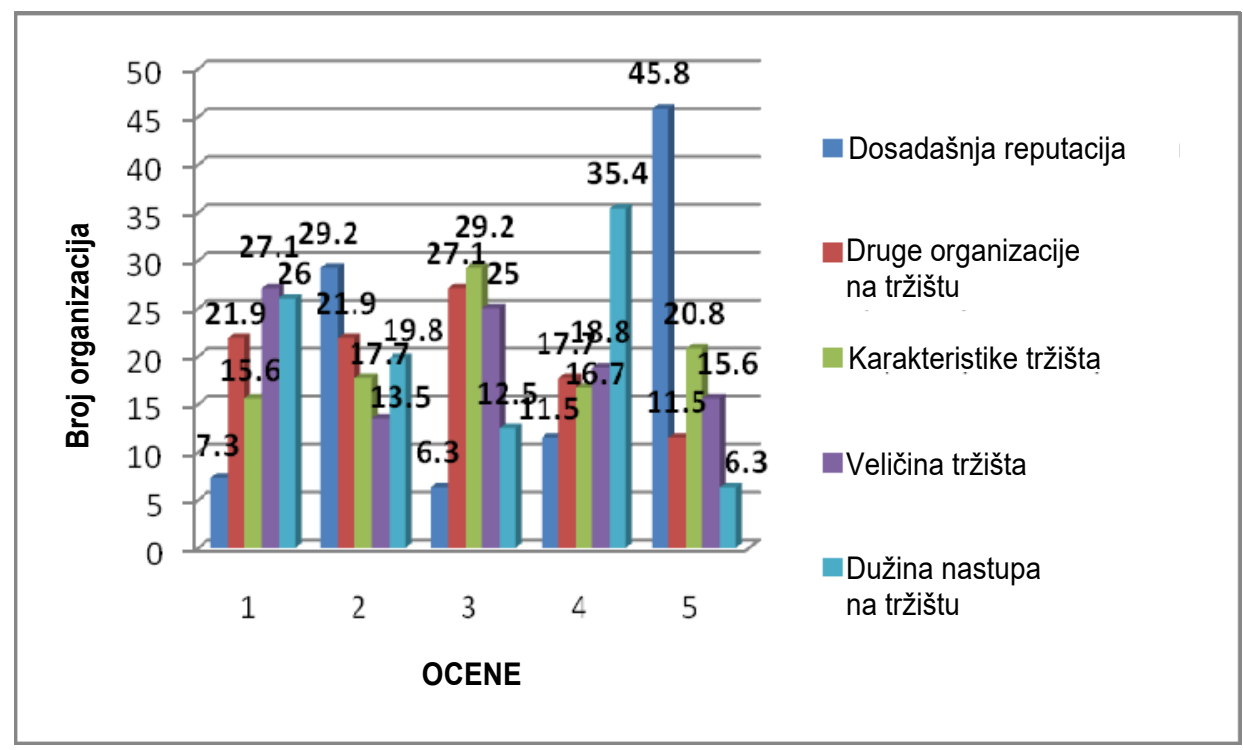

Grafikon 6 - Udeo faktora u \% od značaja za nivo tržišnog učešća Izvor: Ibidem, str. 156.

Od organizacija se dalje tražilo da ocene konkretne faktore poslovne uspešnosti organizacija u uzorku, pri čemu je 1 najmanja, a 5 najviša ocena. U Tabeli 2 predstavljen je značaj tržišnog učešća za poslovni uspeh organizacije. Prosečna ocena značaja tržišnog učešća je 3,84. Vidi se da je najveći broj organizacija značaj tržišnog učešća ocenilo sa ocenom 4 i 5 , prosečna ocena je blizu 4, pa se zaključuje da je tržišno učešće značajno za poslovni uspeh organizacija u uzorku.

Tabela 2 - Ocene značaja tržišnog učešća za poslovni uspeh organizacije

\begin{tabular}{|c|c|c|}
\hline \multicolumn{3}{|c|}{ Značaj tržišnog učešća za poslovni uspeh organizacije } \\
\hline Ocene & Apsolutne frekvencije & Relativne frekvencije \\
\hline 1 & 4 & 4.2 \\
\hline 2 & 2 & 2.1 \\
\hline 3 & 28 & 29.2 \\
\hline 4 & 33 & 34.4 \\
\hline 5 & 29 & 30.2 \\
\hline Ukupno: & 96 & 100.0 \\
\hline
\end{tabular}

Izvor: Ibidem, str. 157.

Tržišno učešće organizacije u nacionalnim okvirima ocenjeno je srednjom vrednošću 3,47. U Tabeli 3 vidi se da je najveći broj organizacija tržišno učešće organizacije u nacionalnim okvirima ocenilo ocenom 3 i 4, pa se zaključuje da je tržišno učešće organizacija u nacionalnim okvirima ocenjeno kao osrednje. 
Vojnoekonomski pregled

Tabela 3 - Ocene tržišnog učešća organizacija u nacionalnim okvirima

\begin{tabular}{|c|c|c|}
\hline \multicolumn{3}{|c|}{ Tržišno učešće organizacije u nacionalnim okvirima } \\
\hline Ocene & Apsolutne frekvencije & Relativne frekvencije \\
\hline 1 & 7 & 7.3 \\
\hline 2 & 11 & 11.5 \\
\hline 3 & 27 & 28.1 \\
\hline 4 & 32 & 33.3 \\
\hline 5 & 19 & 19.8 \\
\hline Ukupno: & 96 & 100.0 \\
\hline
\end{tabular}

Izvor: Ibidem, str. 159.

Srednja vrednost ocena tržišnog učešća organizacije van nacionalnih granica je 2,58. Najveći broj ispitanika ocenilo je tržišno učešće organizacije van nacionalnih granica ocenom 2. Na osnovu ocena i njihove srednje vrednosti može se zaključiti da tržišno učešće organizacija van nacionalnih granica nije na zavidnom nivou. Ocene su predstavljene u Tabeli 4.

Tabela 4 - Ocene tržišnog učešća organizacija van nacionalnih granica

\begin{tabular}{|c|c|c|}
\hline \multicolumn{3}{|c|}{ Tržišno učešće organizacije van nacionalnih granica } \\
\hline Ocene & Apsolutne frekvencije & Relativne frekvencije \\
\hline 1 & 20 & 20.8 \\
\hline 2 & 32 & 33.3 \\
\hline 3 & 21 & 21.9 \\
\hline 4 & 14 & 14.6 \\
\hline 5 & 9 & 9.4 \\
\hline Ukupno: & 96 & 100.0 \\
\hline
\end{tabular}

Izvor: Ibidem, str. 160.

Srednje vrednosti ocena uticaja menadžmenta na povećanje tržišnog učešća u organizacijama je 3,78 . U organizacijama je uticaj menadžmenta na povećanje tržišnog učešća ocenjen u najvećem broju ocenom 4 i ocenom 3, pa se zaključuje da je uticaj menadžmenta ocenjen iznad prosečno na povećanje tržišnog učešća organizacije.

Primenom ANOVA testa uz nivo značajnosti od 0,05 (postoji statistički značajna razlika za vrednosti Sig $\leq 0,05$ ) analizirane su razlike u ocenama tržišnog učešća organizacija različite veličine i različitog nivoa poslovanja. Naknadnim Turkey testom utvrđeno je između kojih organizacija posebno postoji razlika u ocenama.

U Tabeli 5 predstavljeno je između kojih se organizacija različite veličine, javljaju razlike u ocenama značaja tržišnog učešća. Posebna razlika se javlja između organizacija mikro i srednje veličine $($ Sig=0,016<0,05). 
Tabela 5 - Razlike u ocenama značaja tržišnog učešća za poslovnih uspeh organizacija različite veličine

\begin{tabular}{|c|c|c|c|c|c|c|}
\hline \multicolumn{7}{|c|}{ Značaj tržišnog učešća za poslovni uspeh organizacije } \\
\hline \multirow{2}{*}{$\begin{array}{l}\text { (I) Veličina } \\
\text { organizacije }\end{array}$} & \multirow{2}{*}{$\begin{array}{l}\text { (J) Veličina } \\
\text { organizacije }\end{array}$} & \multirow{2}{*}{$\begin{array}{l}\text { Mean } \\
\text { Difference } \\
(I-J)\end{array}$} & \multirow{2}{*}{$\begin{array}{l}\text { Std. } \\
\text { Error }\end{array}$} & \multirow[b]{2}{*}{ Sig. } & \multicolumn{2}{|c|}{ 95\% Confidence } \\
\hline & & & & & $\begin{array}{l}\text { Lower } \\
\text { Bound }\end{array}$ & $\begin{array}{l}\text { Upper } \\
\text { Bound }\end{array}$ \\
\hline \multirow[t]{3}{*}{$\begin{array}{l}\text { Mikro } \\
\text { organizacija }\end{array}$} & $\begin{array}{l}\text { Mala } \\
\text { organizacija }\end{array}$ & -.356 & .253 & .500 & -1.02 & .31 \\
\hline & $\begin{array}{l}\text { Srednja } \\
\text { organizacija }\end{array}$ & $-.906\left(^{*}\right)$ & .297 & .016 & -1.68 & -.13 \\
\hline & $\begin{array}{l}\text { Velika } \\
\text { organizacija }\end{array}$ & -.314 & .291 & .702 & -1.07 & .45 \\
\hline \multirow[t]{3}{*}{$\begin{array}{l}\text { Mala } \\
\text { organizacija }\end{array}$} & $\begin{array}{l}\text { Mikro } \\
\text { organizacija }\end{array}$ & .356 & .253 & .500 & -.31 & 1.02 \\
\hline & $\begin{array}{l}\text { Srednja } \\
\text { organizacija }\end{array}$ & -.550 & .324 & .332 & -1.40 & .30 \\
\hline & $\begin{array}{l}\text { Velika } \\
\text { organizacija }\end{array}$ & .042 & .318 & .999 & -.79 & .87 \\
\hline \multirow[t]{3}{*}{$\begin{array}{l}\text { Srednja } \\
\text { organizacija }\end{array}$} & $\begin{array}{l}\text { Mikro } \\
\text { organizacija }\end{array}$ & $.906\left(^{*}\right)$ & .297 & .016 & .13 & 1.68 \\
\hline & $\begin{array}{l}\text { Mala } \\
\text { organizacija }\end{array}$ & .550 & .324 & .332 & -.30 & 1.40 \\
\hline & $\begin{array}{l}\text { Velika } \\
\text { organizacija }\end{array}$ & .592 & .354 & .345 & -.34 & 1.52 \\
\hline \multirow[t]{3}{*}{$\begin{array}{l}\text { Velika } \\
\text { organizacija }\end{array}$} & $\begin{array}{l}\text { Mikro } \\
\text { organizacija }\end{array}$ & .314 & .291 & .702 & -.45 & 1.07 \\
\hline & $\begin{array}{l}\text { Mala } \\
\text { organizacija }\end{array}$ & -.042 & .318 & .999 & -.87 & .79 \\
\hline & $\begin{array}{l}\text { Srednja } \\
\text { organizacija }\end{array}$ & -.592 & .354 & .345 & -1.52 & .34 \\
\hline
\end{tabular}

Izvor: Ibidem, str. 176.

Razlike se javljaju u: 1) značaju tržišnog učešća za poslovni uspeh organizacije (Sig=0,035<0,05); 2) tržišnom učešću organizacije u nacionalnim okvirima $(S i g=0,021<0,05)$; i van nacionalnih granica ( $\mathrm{Sig}=0,001<0,05)$.

Rezultati u Tabeli 6 pokazuju razlike u ocenama značaja tržišnog učešća za poslovni uspeh u organizacijama različitog nivoa poslovanja, gde se vidi da se razlike u ocenama javljaju kod organizacija koje posluju na lokalnom i regionalnom nivou (Sig $=0,020<0,05)$. 
Tabela 6 - Razlike u ocenama značaja tržišnog učešća za poslovni uspeh organizacija različitog nivoa poslovanja

\begin{tabular}{|c|c|c|c|c|c|c|}
\hline \multicolumn{7}{|c|}{ Značaj tržišnog učešća za poslovni uspeh organizacija } \\
\hline \multirow{2}{*}{$\begin{array}{l}\text { (I) Nivo } \\
\text { poslovanja } \\
\text { organizacije }\end{array}$} & \multirow{2}{*}{$\begin{array}{l}\text { (J) Nivo poslovanja } \\
\text { organizacije }\end{array}$} & \multirow{2}{*}{$\begin{array}{c}\text { Mean } \\
\text { Difference } \\
(I-J)\end{array}$} & \multirow{2}{*}{$\begin{array}{l}\text { Std. } \\
\text { Error }\end{array}$} & \multirow[b]{2}{*}{ Sig. } & \multicolumn{2}{|c|}{ 95\% Confidence } \\
\hline & & & & & $\begin{array}{l}\text { Lower } \\
\text { Bound }\end{array}$ & $\begin{array}{l}\text { Upper } \\
\text { Bound }\end{array}$ \\
\hline \multirow[t]{3}{*}{ Lokalni nivo } & Nacionalni nivo & -.439 & .314 & .504 & -1.26 & .38 \\
\hline & Regionalni nivo & $-.907\left(^{*}\right)$ & .306 & .020 & -1.71 & -.11 \\
\hline & Međunarodni nivo & -.538 & .293 & .264 & -1.30 & .23 \\
\hline \multirow[t]{3}{*}{ Nacionalni nivo } & Lokalni nivo & .439 & .314 & .504 & -.38 & 1.26 \\
\hline & Regionalni nivo & -.467 & .289 & .374 & -1.22 & .29 \\
\hline & Međunarodni nivo & -.098 & .276 & .984 & -.82 & .62 \\
\hline \multirow[t]{3}{*}{ Regionalni nivo } & Lokalni nivo & $.907\left(^{*}\right)$ & .306 & .020 & .11 & 1.71 \\
\hline & Nacionalni nivo & .467 & .289 & .374 & -.29 & 1.22 \\
\hline & Međunarodni nivo & .369 & .266 & .510 & -.33 & 1.06 \\
\hline \multirow[t]{3}{*}{$\begin{array}{l}\text { Međunarodni } \\
\text { nivo }\end{array}$} & Lokalni nivo & .538 & .293 & .264 & -.23 & 1.30 \\
\hline & Nacionalni nivo & .098 & .276 & .984 & -.62 & .82 \\
\hline & Regionalni nivo & -.369 & .266 & .510 & -1.06 & .33 \\
\hline
\end{tabular}

Izvor: Ibidem, str. 183.

U Tabeli 7 predstavljene su razlike u ocenama tržišnog učešća u nacionalnim okvirima između organizacija koje posluju na različitom nivou. Rezultati pokazuju da značajna razlika postoji između organizacija koje posluju na lokalnom i nacionalnom nivou $($ Sig $=0,012<0,05)$.

Tabela 7 - Razlike u ocenama tržišnog učešća organizacija u nacionalnim okvirima, koje posluju na različitom nivou

\begin{tabular}{|c|c|c|c|c|c|c|}
\hline \multicolumn{7}{|c|}{ Tržišno učešće organizacije u nacionalnim okvirima } \\
\hline \multirow{2}{*}{$\begin{array}{l}\text { (I) Nivo poslovanja } \\
\text { organizacije }\end{array}$} & \multirow{2}{*}{$\begin{array}{l}\text { (J) Nivo poslovanja } \\
\text { organizacije }\end{array}$} & \multirow{2}{*}{$\begin{array}{c}\text { Mean } \\
\text { Difference } \\
(I-J)\end{array}$} & \multirow{2}{*}{$\begin{array}{l}\text { Std. } \\
\text { Error }\end{array}$} & \multirow[b]{2}{*}{ Sig. } & \multicolumn{2}{|c|}{ 95\% Confidence } \\
\hline & & & & & $\begin{array}{l}\text { Lower } \\
\text { Bound }\end{array}$ & $\begin{array}{l}\text { Upper } \\
\text { Bound }\end{array}$ \\
\hline \multirow[t]{3}{*}{ Lokalni nivo } & Nacionalni nivo & $-1.111\left(^{*}\right)$ & .353 & .012 & -2.03 & -.19 \\
\hline & Regionalni nivo & -.631 & .343 & .262 & -1.53 & .27 \\
\hline & Međunarodni nivo & -.498 & .329 & .433 & -1.36 & .36 \\
\hline \multirow[t]{3}{*}{ Nacionalni nivo } & Lokalni nivo & $1.111\left(^{*}\right)$ & .353 & .012 & .19 & 2.03 \\
\hline & Regionalni nivo & .480 & .325 & .454 & -.37 & 1.33 \\
\hline & Međunarodni nivo & .613 & .309 & .203 & -.20 & 1.42 \\
\hline \multirow[t]{3}{*}{ Regionalni nivo } & Lokalni nivo & .631 & .343 & .262 & -.27 & 1.53 \\
\hline & Nacionalni nivo & -.480 & .325 & .454 & -1.33 & .37 \\
\hline & Međunarodni nivo & .133 & .298 & .970 & -.65 & .91 \\
\hline \multirow[t]{3}{*}{ Međunarodni nivo } & Lokalni nivo & .498 & 329 & .433 & -.36 & 1.36 \\
\hline & Nacionalni nivo & -.613 & .309 & .203 & -1.42 & .20 \\
\hline & Regionalni nivo & -.133 & .298 & .970 & -.91 & .65 \\
\hline
\end{tabular}

Izvor: Ibidem, str. 184. 
U Tabeli 8 predstavljene su razlike u ocenama tržišnog učešća organizacija van nacionalnih granica koje posluju na različitim nivoima poslovanja. Rezultati pokazuju da se posebno razlikuju ocene organizacija koje posluju na lokalnom i međunarodnom nivou (Sig $=0,009<0,05)$, organizacija koje posluju na nacionalnom i regionalnom nivou (Sig=0,049<0,05), kao i organizacija koje posluju na nacionalnom i međunarodnom nivou $(\mathrm{Sig}=0,005<0,05)$.

Tabela 8 - Razlike u ocenama tržišnog učešća organizacije van nacionalnih granica

\begin{tabular}{|c|c|c|c|c|c|c|}
\hline \multicolumn{7}{|c|}{ Tržišno učešće organizacije van nacionalnih granica } \\
\hline \multirow{2}{*}{$\begin{array}{c}\text { (I) Nivo } \\
\text { poslovanja } \\
\text { organizacije }\end{array}$} & \multirow{2}{*}{$\begin{array}{l}\text { (J) Nivo poslovanja } \\
\text { organizacije }\end{array}$} & \multirow{2}{*}{$\begin{array}{l}\text { Mean } \\
\text { Differenc } \\
\text { e }(I-J)\end{array}$} & \multirow{2}{*}{$\begin{array}{l}\text { Std. } \\
\text { Error }\end{array}$} & \multirow[b]{2}{*}{ Sig. } & \multicolumn{2}{|c|}{ 95\% Confidence } \\
\hline & & & & & $\begin{array}{l}\text { Lower } \\
\text { Bound }\end{array}$ & $\begin{array}{l}\text { Upper } \\
\text { Bound }\end{array}$ \\
\hline \multirow[t]{3}{*}{ Lokalni nivo } & Nacionalni nivo & .000 & .365 & 1.000 & -.96 & .96 \\
\hline & Regionalni nivo & -.880 & .355 & .070 & -1.81 & .05 \\
\hline & Međunarodni nivo & $-1.097\left(^{*}\right)$ & .340 & .009 & -1.99 & -.21 \\
\hline \multirow[t]{3}{*}{ Nacionalni nivo } & Lokalni nivo & .000 & .365 & 1.000 & -.96 & .96 \\
\hline & Regionalni nivo & $-.880\left(^{*}\right)$ & .336 & .049 & -1.76 & .00 \\
\hline & Međunarodni nivo & $-1.097\left(^{*}\right)$ & .320 & .005 & -1.93 & -.26 \\
\hline \multirow[t]{3}{*}{ Regionalni nivo } & Lokalni nivo & .880 & .355 & .070 & -.05 & 1.81 \\
\hline & Nacionalni nivo & $.880\left(^{*}\right)$ & .336 & .049 & .00 & 1.76 \\
\hline & Međunarodni nivo & -.217 & .309 & .896 & -1.02 & .59 \\
\hline \multirow[t]{3}{*}{$\begin{array}{l}\text { Međunarodni } \\
\text { nivo }\end{array}$} & Lokalni nivo & $1.097\left(^{*}\right)$ & .340 & .009 & .21 & 1.99 \\
\hline & Nacionalni nivo & $1.097\left(^{*}\right)$ & .320 & .005 & .26 & 1.93 \\
\hline & Regionalni nivo & .217 & .309 & .896 & -.59 & 1.02 \\
\hline
\end{tabular}

Izvor: Ibidem, str. 186.

\section{Korelaciona analiza}

Korelaciona analiza je imala za cilj da opiše jačinu i smer veze između veličine organizacije, nivoa poslovanja i dužine poslovanja sa faktorima od značaja za ostvarivanje profitabilnog udela na tržištu. Koeficijenti Pirosonove korelacije (r) mogu imati vrednosti od -1 do +1 . Predznak pokazuje da li je korelacije pozitivna ili negativna. Apsolutna vrednost tog koeficijenta (kada se zanemari predznak) pokazuje jačinu veze i to (Cohen, 1998):

- mala korelacija $r=0,10$ do 0,29 ;

- srednja korelacija $r=0,30$ do 0,49 ;

- velika korelacija r=0,50 do 1,0.

U Tabeli 9 predstavljena je korelacija faktora od značaja za nivo tržišnog učešća (dosadašnja reputacija, druge organizacije na tržištu, karakteristike tržišta, veličina tržišta i dužina nastupa na tržištu) sa ocenama tržišne pozicije i uspešnosti organizacija. 
Vojnoekonomski pregled

Tabela 9 - Korelacija faktora od značaj za tržišno učešće i uspešnost organizacije

\begin{tabular}{|c|c|c|c|c|c|c|}
\hline & & $\begin{array}{c}\text { Dosadašnja } \\
\text { reputacija }\end{array}$ & $\begin{array}{c}\text { Druge } \\
\text { organizacije } \\
\text { na tržištu }\end{array}$ & $\begin{array}{l}\text { Karak- } \\
\text { teristike } \\
\text { tržišta }\end{array}$ & $\begin{array}{l}\text { Veličina } \\
\text { tržišta }\end{array}$ & $\begin{array}{l}\text { Dužina } \\
\text { nastupa } \\
\text { na tržištu }\end{array}$ \\
\hline \multirow{3}{*}{$\begin{array}{l}\text { Značaj tržišnog } \\
\text { učešća za } \\
\text { poslovni uspeh } \\
\text { organizacije }\end{array}$} & $\begin{array}{l}\text { Pearson } \\
\text { Correlation }\end{array}$ & -.035 & -.078 & -.066 & .024 & .149 \\
\hline & Sig. (2-tailed) & .732 & .452 & .523 & .814 & .147 \\
\hline & $\mathrm{N}$ & 96 & 96 & 96 & 96 & 96 \\
\hline \multirow{3}{*}{$\begin{array}{l}\text { Tržišno učešće } \\
\text { organizacije u } \\
\text { nacionalnim } \\
\text { okvirima }\end{array}$} & $\begin{array}{l}\text { Pearson } \\
\text { Correlation }\end{array}$ & -.134 & -.019 & -.001 & .128 & .039 \\
\hline & Sig. (2-tailed) & .194 & .851 & .989 & .212 & .704 \\
\hline & $\mathrm{N}$ & 96 & 96 & 96 & 96 & 96 \\
\hline \multirow{3}{*}{$\begin{array}{l}\text { Tržišno učešće } \\
\text { organizacije van } \\
\text { nacionalnih } \\
\text { granica }\end{array}$} & $\begin{array}{l}\text { Pearson } \\
\text { Correla-tion }\end{array}$ & -.024 & .039 & -.172 & .053 & .098 \\
\hline & Sig. (2-tailed) & .814 & .703 & .093 & .605 & .344 \\
\hline & $\mathrm{N}$ & 96 & 96 & 96 & 96 & 96 \\
\hline \multirow{3}{*}{$\begin{array}{l}\text { Uticaj } \\
\text { menadžmenta na } \\
\text { povećanje } \\
\text { tržišnog učešća u } \\
\text { organizaciji }\end{array}$} & $\begin{array}{l}\text { Pearson } \\
\text { Correla-tion }\end{array}$ & $\left..3311^{* *}\right)$ & $-.300\left(^{* *}\right)$ & $-.254\left(^{*}\right)$ & -.200 & $.378\left(^{* \star}\right)$ \\
\hline & Sig. (2-tailed) & .001 & .003 & .012 & .051 & .000 \\
\hline & $N$ & 96 & 96 & 96 & 96 & 96 \\
\hline
\end{tabular}

${ }^{*}$ Correlation is significant at the 0.05 level (2-tailed).

${ }^{* *}$ Correlation is significant at the 0.01 level (2-tailed).

Izvor: Ibidem, str. 209.

Rezultati pokazuju da postoji pozitivna korelacija srednje jačine između $(r=0,331)$ uticaja menadžmenta na povećanje tržišnog učešća organizacije i dosadašnje reputacije, pozitivna korelacija srednje jačine uticaja menadžmenta i dužine nastupa na tržištu $(r=0,378)$, kao i negativna korelacija srednje jačine između uticaja menadžmenta i drugih organizacija na tržištu ( $r=-0,300)$. Rezultati ukazuju da se povećanjem uticaja menadžmenta na tržišno učešće povećava značaj dosadašnje reputacije i dužine nastupa na tržištu, ali se smanjuje uticaj drugih organizacija kao faktora od značaja za nivo tržišnog učešća.

\section{Diskusija}

Sprovedeno istraživanje obuhvatilo je 96 organizacija različite veličine (mikro, male, srednje, velike organizacije), nivoa poslovanja (lokalni, nacionalni, regionalni, međunarodni nivo), trajanja poslovanja i delatnosti (uslužna, proizvodna i uslužna i proizvodna). Svrha istraživanja je bila da se ocene faktori značajni za nivo tržišnog učešća organizacija u Srbiji, među kojima je poseban akcenat stavljen na karakteristike i veličinu tržišta, reputaciju organizacije i dužinu njenog nastupa na tržištu, kao i značaj drugih etabliranih organizacija na tržištu. 
Rezultati na uzorku pokazuju da se tržišno učešće organizacija pokazalo kao značajno za njihov poslovni uspeh. Značaj tržišnog učešća za poslovni uspeh domaće organizacije ocenjen je ocenom 3,47. Najbitniji faktor od značaja za nivo tržišnog učešća je dosadašnja reputacija ocena 3,59 , slede karakteristike tržišta, veličina tržišta, dužina nastupa na tržištu i druge organizacije na tržištu. Rezultati istraživanja pokazuju da uspešnost organizacije raste sa relativnim rastom tržišnog učešća, ali se ostvarivanje velikog tržišnog učešća na ciljnom tržištu neće automatski poboljšati.

Istraživanjem razlika u ocenama faktora od značaja za nivo tržišnog učešća rezultati pokazuju da se bez obzira na veličinu organizacije bitno ne razlikuju ocene od značaja za nivo tržišnog udela, sem kod dosadašnje reputacije i karakteristika tržišta kao faktori od kojih zavisi nivo tržišnog učešća. Posmatranjem tržišnog učešća organizacije može se zaključiti da veličina organizacije ne utiče značajno na uspešnost njihovog poslovanja. Ukoliko se posmatra nivo tržišnog učešća rezultati pokazuju da povećanjem uticaja menadžmenta u pravcu povećanja tržišnog učešća organizacije, povećava se značaj dosadašnje reputacije i dužina nastupa na tržištu, dok se značaj drugih organizacija na tržištu smanjuje.

\section{Zaključak}

Bilo koja organizacija koja posluje na tržištu kontinuirano teži da poveća svoje tržišno učešće, s obzirom da kako rezultati istraživanja pokazuju postoji pozitivna korelacija između tržišnog učešća i poslovnog uspeha (profitabilnosti) organizacije. Organizacije koriste tržišno učešće kao jedan od važnijih ciljeva svog menadžmenta, s obzirom da je ponekad lakše ponovo ostvariti veći iznos dobiti nego povratiti izgubljeni deo tržišnog učešća. Da bi srpska organizacija izgradila povoljnu i neranjivu tržišnu poziciju, koja će joj obezbediti relativnu stabilnost u turbulentnom ambijentu tržišnog poslovanja, potrebno je da upozna i koristi razuđene i različite metode ostvarivanja učešća na tržištu.

Ishodišni korak u sagledavanju nivoa uspešnosti je analiza učesnika na tržištu. Nivo uspešnosti na nekom tržištu najpre se meri kroz učešće pojedinačnih učesnika. Indikatori nivoa tržišnog učešća omogućavaju organizaciji da sagleda konkurentsku poziciju u odnosu na rivale. Ako tržišno učešće organizacije opada, znak je da je proizvod postao nekonkurentan na datom tržištu. Stoga je potrebno da se kontinuirano preispitaju kako faktori konkurentnosti tako i faktori koji bitno opredeljuju nivo tržišnog učešća da bi se poslovni uspeh organizacije osigurao.

\section{Literatura}

[1] Aaker, D., Kumar, V., Day, G. (2008). Marketing research. Copyright CFaculty of Economics, Belgrade: $52-53$.

[2] Amato, H. L., Wilder, P. R. (2004). Global competition and global markets: Some empirical results. International Business Review, 16, Elsevier, стр. 412.

[3] Buzzell, R. D., Wiersema, F. D. (1981). Successful Sharebuilding Strategies. Harvard Business Review, 59(1): стр. 135-144.

[4] Carlton, W. D., Perflof, M. J. (2005). Modern Industrial Organization, Adision Wesley, Boston, USA. 
[5] Cohen, J. (1998). Statistical power analysis for the behavioral sciences, New York, Lawrence Erlbaum Associates.

[6] Ћурчић, Н. (2017). Фактори конкурентности и тржишно учешће организације као претпоставка пословног успеха. ДД - Факултет за примењени менаџмент, економију и финансије, Београд.

[7] Ћурчић, Н. (2018). Пословни успех савремене организације. Институт за економику пољопривреде, Београд.

[8] Ђорђевић, Б. (2014). Модели владања тржиштем. Свен, Ниш.

[9] Hamermesh, R. G., Anderson, M. J. Jr. (1978). Strategies for Low Market Share Businesses, Harvard Business Review, 56(3): стр. 95-102.

[10] Hellofs, L., Jacobson, R. (1999). Market Share and Customers' Perceptions of Quality: When Can Firms Grow Their Way to Higher versus Lower Quality? Journal of Marketing , Vol. 63, No. 1 (Jan.,), pp. 16-25.

[11] Lipezynski, J., Wilson, J. (2001). Industrial Organisation - An Analysis of Competitive Markets. Prentice Hall, Harlow, UK, стр.110.

[12] Kotler, F. (1989). Upravljanje marketingom II, Informator, Zagreb, str. 772-73.

[13] Kotler, Ph, (2000), Marketing Management, Millenium Edition, Tenth Edition, Prentice-Hall,

[14] Милисављевић, М. (2002). Маркетинг, Савремена администрација , Београд.

[15] Namiki, M. (2011). Success ful Share-building Strategies for High - technology Companies. College of Business, Graduate School of Business Administration, Rikkyo University, Business Review, No.4 стр. 50-52.

[16] Perren, L., (2000), Factors in the growth of micro-enterprises (part 2): exploring the implications, Journal of small business and enterprise development, 7(1), стр. 58-68.

[17] Porter, M. E. (1980). Competitive Strategy, New York, Free Press.

[18] Samuelson, A. P., Nordhaus, D., W. (2001). Microeconomics, Irwin, McGraw-Hill.

[19] Schoeffler, S., Buzzell, R. D. (1974). Impact of Strategic Planning on Profit Performance. Harvard Business Review,52(2) стр. 137-145.

[20] Стојановић, Б., (2005). Тржишна економија. Економски факултет, Ниш.

[21] Tadić, J., Boljević, A. (2015). Integration of Critical Success Factors in Order to Improve Performance of the Company, Strategic Management, Vol. 20, No. 1, pp. 026-033.

[22] Waldman, E. D., Jensen, E. (2001). Industrial Organiyation, Theory and Practice, Addison Wesley Longman, New York, стр. 95. 